\title{
A SUPPORTING AID FOR BEEF CATTLE INVESTMENT OF FARM HOUSEHOLD IN CENTRAL JAVA
}

\author{
T. Ekowati ${ }^{1,3}$, D.H. Darwanto ${ }^{1}$, S. Nurtini ${ }^{2}$ and A. Suryantini ${ }^{1}$ \\ ${ }^{1}$ Faculty of Agriculture, Gadjah Mada University, \\ Jl. Flora, Bulaksumur Campus, Yogyakarta - Indonesia \\ ${ }^{2}$ Faculty of Animal Sciences, Gadjah Mada University, \\ Jl. Fauna, Bulaksumur Campus, Yogyakarta - Indonesia \\ ${ }^{3}$ Permanent Address : Faculty of Animal Agriculture, Diponegoro University, \\ Tembalang Campus, Semarang 50275 - Indonesia \\ Corresponding E-mail:tiekowati@yahoo.co.id
}

Received December 27, 2011; Accepted February 08, 2012

\begin{abstract}
ABSTRAK
Penelitian dilakukan dengan tujuan untuk menganalisis beberapa faktor yang mempengaruhi produksi, pendapatan, konsumsi rumahtangga dan investasi usaha sapi potong. Lokasi penelitian ditentukan secara purposive sampling berdasarkan populasi sapi potong dan lokasi terpilih yaitu Kabupaten Rembang, Blora, Grobogan, Boyolali dan Wonogiri. Responden peternak ditentukan dengan metode quota sampling, setiap kabupaten diambil 40 responden. Data dianalisis dengan analisis regresi simultan dan diestimasi dengan Two Stage Least Square (TSLS). Hasil penelitian menunjukkan bahwa secara simultan variabel independen berpengaruh nyata terhadap variabel dependen (produksi, pendapatan, konsumsi dan investasi sapi potong) dengan probabilitas $\mathrm{F}$ hitung 0,0000 dan adjusted $\mathrm{R}^{2}$ masing-masing adalah $91 \% ; 89 \% ; 96 \%$ and $62 \%$. Analisis simulasi penerapan agribisnis yang terdiri atas 1) penurunan service per conception 15\%; 2) kenaikan harga induk dan jumlah sapi potong masing-masing $15 \%$; 3) kenaikan harga beras dan jumlah anggota keluarga masing-masing $15 \%$ dan 4) peningkatan pendapatan dan harga ternak sapi potong masing-masing $10 \%$ menyebabkan peningkatan konsumsi rumah tangga $0,446 \%$ dan investasi sapi potong 5,14\% sedangkan produksi dan pendapatan tidak berubah. Kesimpulan penelitian adalah variabel independent secara simultan berpengaruh terhadap produksi, pendapatan, konsumsi dan investasi sapi potong dan adanya perubahan penggunaan input maupun harga hanya berpengaruh terhadap konsumsi dan investasi.
\end{abstract}

Kata kunci: regresi simultan, produksi, pendapatan, konsumsi rumahtangga, investasi sapi potong

\begin{abstract}
The research was conducted to analyze some factors influencing production, income, farm household consumption and investment of farm household beef cattle in Central Java. Five districts were purposively chosen for research location based on the number of beef cattle population, namely Rembang, Blora, Grobogan, Boyolali and Wonogiri. Forty respondents of each district were chosen randomly using quota sampling. Data were analyzed through Simultaneous Regression and estimated by Two Stage Least Square (TSLS). The results showed that independent variables were simultaneously significant to dependent variables (production, income, farm household consumption and investment) with the Probability F test 0.0000 and adjusted $\mathrm{R}^{2}$ were $91 \% ; 89 \%$; $96 \%$; 62\%, respectively. The simulation's analysis of agribusiness implementation consisted of 1) decreasing $15 \%$ of service per conception, 2) increasing of beef cattle breed and number of beef cattle $15 \%$ respectively, 3) raising of price of rice and number of household member $15 \%$ respectively and 4) increasing of income and price of beef cattle $10 \%$ respectively influenced to farm household consumption and investment $0.446 \%$ and $5.14 \%$, respectively, meanwhile production and income did not change. The research can be concluded that the independent variables simultaneously significant influenced to production, income, farm household consumption and beef cattle investment. The simulation of changing usage of input factor and price significantly influenced to farm household consumption and beef cattle investment.

Keywords : simultaneous regression analysis; production, income, farm household consumption, beef cattle investment.
\end{abstract}




\section{INTRODUCTION}

The important component of agriculture sector is livestock and an insurance against harvest failures and a source of easily cashable investment capital. Ninety two percent farmer families have opinion that livestock is the only first level sustainable source of livelihood (Herani, 2008). Therefore, beef cattle farming is kept living among those farm households in the village as one of their livelihoods. Livestock farming is a system influenced by physical, biotic, and social economic factors where these also become challenges for an agribusiness management (Amir and Knipscheer, 1989). On farmer level, some efforts to raise productivity can be taken by improving its management (Saragih, 2003). Farming management is related to how to allocate the resources in order to gain profit through production, consumption, and investment. Singh et al. (1986) stated that on farming level; subsystem decisions on production, consumption, and labor are simultaneously formulated. However, the condition confirmed that many of these activities are nowadays turned to semi-commercial but decisions on production, consumption and labor are still correlated. Concerned to this matter, a concept of cattle farming was implemented through a comparative profit measurement of production factor or resource. That was in line with Ponzoni and Newman (1989) and Harris and Newman (1994) that the general aim of farm animal improvement is to increase efficiency of production to get profit. The challenge faced by farmer now is how to use production factors efficiently in order to gain profit so that its improvement can be realized by allocating part of investment.

Beef cattle investment decision provides an excellent opportunity to increase the economic efficiency of beef cattle production. The investment problem that face beef cattle producers are of interest to beef cattle producers, educators and financial institutions involved in lending to beef cattle producing firms (Falconer et al., 1996).

Based on the beef cattle farmer's problem related to the allocation of production factors and how to increase income to develope beef cattle farm through investment so the farmers need supporting aid. Supports for beef cattle farming among farm-households are simulated through improvement on the usage of input factor, the rise of cattle price and total household income towards production capacity, income, consumption and investment.

Taking into consideration the abovementioned, this research was conducted to analyze some factors influencing production, income, farm household consumption, beef cattle investment and supporting aid for farm household in Central Java.

\section{MATERIALS AND METHODS}

Descriptive research design was used for research method, it involves observing and describing the behavior of a subject and describes data or characteristics about the population being studied (Nasir, 1988). Besides that, survey method was used to collect data by asking questions to people who are thought to have needed information related to beef cattle firm. Five districts were purposively chosen based on the number of beef cattle population (BPS, 2010), namely Blora, Grobogan, Rembang, Boyolali and Wonogiri, respectively. The number of respondents were 200 farmers which were chosen randomly using quota sampling, so that each region consists of 40 respondents. The data were analyzed descriptively and statistically through simultaneous regression analysis.

Econometric model formulated is a combination of mathematic and statistic models which correlating variables as a stochastic element and meets the criteria of economic, statistic and econometric (Koutsoyiannis, 1985; Pyndick and Rubinfeld, 2005; Gujarati, 2004). Identification test of the model according to order condition was taken to identify structural equation as a model of simultaneous equation which meet the criteria: $(\mathrm{K}-\mathrm{k}) \geq(\mathrm{m}-1)$, where $\mathrm{K}=$ total of exogenous variables in the model, $\mathrm{k}=$ total of exogenous variables in the equation, and $\mathrm{m}=$ total of endogenous variables in the equation. If $\mathrm{K}-\mathrm{k}$ $>\mathrm{m}-1$, then the result is over identified, which means that the equation can be estimated. The result of order condition test is suggested in Table 1. From the equation in Table 1, pre-determinant variables were found:

LC; NB; OWT; SC; AF; AC; AM; YB, AI, PB; NBC; PF, PC; NHM; PR; PC; PS; PFish; PM; PMilk; PT; PO; PBC; AH; AW; D.

Then, model validation was taken in order to find whether the model used is valid for decision simulation or not. Statistic criteria used for model validation are Mean Square Error (RMSE) and UTheil's inequality coefficient (U) (Pyndick and Rubinfeld, 2005). 
Table 1. Identification of Sufficiency Requirement to 11 Equations

\begin{tabular}{|c|c|c|c|c|}
\hline No. & Equations & K-k & $\mathrm{m}-1$ & Ident \\
\hline & $\mathrm{BCCP}=\mathrm{LC}+\mathrm{IC}$ & $26-1=25$ & $2-1=1$ & Over \\
\hline 2. & $\mathrm{IC}=\mathrm{CB}+\mathrm{CF}+\mathrm{CC}+\mathrm{CM}+\mathrm{CR}+\mathrm{CE}$ & $26-6=20$ & $1-1=0$ & Over \\
\hline 3. & $\begin{array}{l}\operatorname{LnPROD}=\operatorname{Lna}_{0}+a_{1} \operatorname{LnNB}+a_{2} \operatorname{LnOWT}+a_{3} \operatorname{LnSC}+a_{4} \operatorname{LnAF}+ \\
a_{5} \operatorname{LnAC}+a_{6} \operatorname{LnAM}+a_{7} \operatorname{LnYB}+a_{8} \operatorname{LnIA}+\mu_{1}\end{array}$ & $26-8=18$ & $1-1=0$ & Over \\
\hline 4. & $\mathrm{INC}=\mathrm{b}_{0}+\mathrm{b}_{1} \mathrm{~PB}+\mathrm{b}_{2} \mathrm{NBC}+\mathrm{b}_{3} \mathrm{PF}+\mathrm{b}_{4} \mathrm{PC}+\mathrm{b}_{5} \mathrm{LC}+\mathrm{b}_{6} \mathrm{D}+\mu_{2}$ & $26-6=20$ & $1-1=0$ & Over \\
\hline 5. & $\mathrm{INBC}=\mathrm{RBC}-\mathrm{BCCP}$ & $26-0=26$ & $3-1=2$ & Over \\
\hline 6. & $\mathrm{RBC}=\mathrm{PROD} \times \mathrm{PBC}$ & $26-1=25$ & $2-1=1$ & Over \\
\hline 7. & $\mathrm{HHTI}=\mathrm{INCB}+\mathrm{INBC}$ & $26-1=25$ & $2-1=1$ & Over \\
\hline 8. & $\begin{array}{l}\mathrm{LnFC}=\mathrm{Lnc}_{0}+\mathrm{c}_{1} \operatorname{LnNHM}+\mathrm{c}_{2} \operatorname{LnPR}+\mathrm{c}_{3} \operatorname{LnPC}+\mathrm{c}_{4} \operatorname{LnPS}+ \\
\mathrm{c}_{5} \mathrm{LnPFish}+\mathrm{c}_{6} \operatorname{LnPM}+\mathrm{c}_{7} \operatorname{LnPMilk}+\mathrm{c}_{8} \operatorname{LnPT}+\mathrm{c}_{9} \operatorname{LnPO}+ \\
\mathrm{c}_{10} \operatorname{LnAH}+\mathrm{c}_{11} \operatorname{LnAW} c_{12} \operatorname{LnINBC}+\mu_{3}\end{array}$ & $26-12=14$ & $1-1=0$ & Over \\
\hline & $\mathrm{TC}=\mathrm{FC}+\mathrm{NFC}$ & $26-0=26$ & $3-1=2$ & Over \\
\hline & $\begin{array}{l}\operatorname{LnBCI}=\operatorname{Lnd}_{0}+d_{1} \operatorname{LnNBC}+d_{2} \operatorname{LnOWT}+d_{3} \operatorname{LnPBC}+ \\
d_{4} \operatorname{LnTC}+d_{5} \operatorname{LnAI}+\mu_{4}\end{array}$ & $26-5=21$ & $3-1=2$ & Over \\
\hline 11. & $\mathrm{NFE}=\mathrm{NFC}+\mathrm{BCI}$ & $26-0=26$ & $3-1=2$ & Over \\
\hline
\end{tabular}

Notes :

BCCP (Beef cattle cost production); LC (labor cost); IC (input cost); CB (Cost of breed); CF(cost of forages); $\mathrm{CC}$ (cost of concentrate); $\mathrm{CM}$ (cost of medicine); $\mathrm{CE}$ (cost of equipment); CR (cost of reproduction); PROD (production); OWT (outflow of working time); SC (Service per conception); AF (amount of forages); AC (amount of concentatre); AM (amount of medicine); YB (Years of Breed); AI (Agribusiness Implementation); INC (income); PB (price of breed); NBC (number of beef cattle); PF (price of forages); PC (price of concentrate); D: dummy variable (kind of beef cattle); INCBC (income of beef cattle); RBC (revenue of beef cattle); PBC (price of beef cattle); HHTI (Household total income); INBC (income of non beef cattle); FC (food consumption); NHM (number of household member); PR (price of rice); PC (price of corn); PS (Price of sugar); PFish (price of fish); PM (price of meat); PMilk (price of milk); PT (Price of tobacco); PO (price of oil); AH (Age of husband); AW (age of wife); TC (total consumption); NFC (Non food counsumption); BCI (beef cattle investment); NFE (Non Food Expenditure).

Supporting aid for farm household was simulated by 1) improvement of agribusiness subsystem implementation and lowering service per conception of $5 \% ; 2$ ) increasing $15 \%$ of price of cattle breed and number of beef cattle; 3) raising $15 \%$ of rice price and number of family members; 4) increasing $10 \%$ of income and price of beef cattle.

\section{RESULTS AND DISCUSSION}

\section{Profile of Beef Cattle Farming in Central Java}

Beef cattle is one of big farming commodities which mostly managed by farmers in Central Java, both as people and corporate farming. The population of beef cattle farming in Central Java from 2006-2010 is turned to raise with growth rate of $2.8 \%$ and population in 2010 achieved $1,554,458$ cattle. The population of beef cattle is spread through all of Central Java with the most populated areas found in 5 regencies, those are Blora, Grobogan, Rembang, Boyolali, and Wonogiri

\section{Characteristics of the Respondents}

The result of the study revealed that $89 \%$ respondents were in their productive age and $56.5 \%$ attended primary school. Moreover, most 
Table 2. Analysis Result of Factors Influencing Beef Cattle Production

\begin{tabular}{|c|c|c|c|}
\hline Variables & Expected Sign & Coeficient & Probability \\
\hline Intercept & + & $10.01947 * * *$ & 0.0000 \\
\hline Ln NC & + & $0.809773 * * *$ & 0.0000 \\
\hline Ln OWT & + & $0.190888 * * *$ & 0.0092 \\
\hline Ln SC & - & $-0.046795^{*}$ & 0.0593 \\
\hline $\operatorname{Ln} \mathrm{AF}$ & + & $0.071804 * *$ & 0.0235 \\
\hline Ln AC & + & $0.008651 * * *$ & 0.0036 \\
\hline Ln AM & + & 0.026894 & 0.1318 \\
\hline Ln YB & + & $0.023518^{*}$ & 0.0739 \\
\hline Ln AI & + & $0.616217 * * *$ & 0.0000 \\
\hline Probability of F-test & & & 0.0000 \\
\hline R-square & & & 0.915815 \\
\hline Adjusted R-square & & & 0.912289 \\
\hline
\end{tabular}

*Significant at $\alpha=10 \%, * *$ Significant at $\alpha=5 \%$ and $* * *$ Significant at $\alpha=1 \%$

of the respondents had experience to manage a beef cattle farming for 19.895 years. Most of the respondent $(81 \%)$ worked as food crop farmers, only $4 \%$ of the respondents had main occupation as beef cattle farmers and it has 8 hours-work day.

The respondents were consisted of $56.50 \%$ graduated from Elementary School, $22.00 \%$ Junior High School and $11.00 \%$ Senior High School. According to the data, $38.50 \%$ respondents have worked for their farming more than 20 years. About $67.50 \%$ respondents have 34 family members with the average of 3.12 people. On average, the cattle ownership raised by the respondents was 5.21 cattle or 4.268 Animal Unit (AU).

\section{The Analysis of Production, Income,} Consumption and Investment

Analysis of production, income, consumption and investment discussed matters were related to the allocation of input factor usage in beef cattle farming. From total household income, it was suggested that the allocation of household consumption and improvement of beef cattle farming was directed to the investment. Production cost of beef cattle farming can be estimated by the use of variable cost and fixed cost. The production cost was IDR $8,254,828.287 /$ year consisted of variable cost IDR
7,853,442.525 and fixed cost IDR 401,385.762. In addition, the highest component in this production cost was forage i.e. IDR 3,919,698 (47.483\%). This showed that the feed usage was a dominant requirement must be allocated by the farmer for beef cattle farming. The result was in line to Lestari et al. (2011) that feed is one of the environmental factors influencing the productivity of livestock.

Income is the difference between revenue and cost production (Debertin, 1986). In this research, the cost component was estimated as a cost i.e. allocation of input usage was valued as cost, thus the approach used here was farmer's profit. The Income of beef cattle farmer was IDR $1,934,861.713$ /year consisted of revenue IDR $10,189,690$ and production cost IDR $8,254,828.287$. The beef cattle farmer's income per month was lower than the province of minimum wages namely IDR $161,238,476$ and IDR 675,000 respectively. Thus many efforts are needed to improve this activity through improving the attitude of beef cattle farmer to agribusiness implementation (Ekowati et al., 2011).

Analysis of factors influencing the beef cattle production is presented in Table 2. The result showed that all independent variables were simultaneously significant correlated with production with probability of F-test of 0.0000 and adjusted $\mathrm{R}^{2}$ of $91 \%$. The $91 \%$ of adjusted $\mathrm{R}^{2}$ 
Tabel 3. Analysis Result of Factors Influencing Beff Cattle Farmer's Income

\begin{tabular}{|c|c|c|c|}
\hline Variables & Expected Sign & Coefficient & Probability \\
\hline Intercept & + & $7445.635^{* * *}$ & 0.0000 \\
\hline $\mathrm{PB}$ & - & $-2652.378 * * *$ & 0.0000 \\
\hline NBC & + & $2.336677^{* *}$ & 0.0426 \\
\hline $\mathrm{PF}$ & - & $-6275.462 * * *$ & 0.0027 \\
\hline PC & - & -7.626540 & 0.9662 \\
\hline $\mathrm{LC}$ & - & $-0.907821 * * *$ & 0.0000 \\
\hline Dummy variable & + & $60.25308 * * *$ & 0.0000 \\
\hline Probability of F test & & & 0.0000 \\
\hline R-square & & & 0.897144 \\
\hline Adjusted R-square & & & 0.893946 \\
\hline
\end{tabular}

*Significant at $\alpha=10 \%, * *$ Significant at $\alpha=5 \%$ and $* * *$ Significant at $\alpha=1 \%$

means $91 \%$ of independent variables were significantly correlated towards dependent variable and $10 \%$ was correlated with other factors. Besides that, other variables with significant correlation, in partial, towards production were NB; OWT, AC and AI with $1 \%$ of significance. Furthermore, AC has significant correlation of $5 \%$ and variables of $\mathrm{SC}$ and $\mathrm{YB}$ have significant correlation of $10 \%$. Also, regression coefficient of all variables which significantly correlated with production were between $0-1(0<\mathrm{E}<1)$, it mean that production function of beef cattle farming was found in area II i.e. input factor used by the farmers was in rational limit.

Factors influencing the income of beef cattle farming were analyzed using profit function measure which was generated from productive equation where input used was normalized by output price. The estimation result suggested that expected sign of variable correlating to endogenous variable of beef cattle farming income was in accordance with the economic criteria. The result of this analysis is presented in Table 3.

The result suggested that all independent variables, simultaneously, were significantly correlated with income with probability of F-test 0.0000 and adjusted $\mathrm{R}^{2}$ of $89 \%$. That mean $89 \%$ of independent variables influenced the income but the other $11 \%$ was influenced by other factors. Variables with significant correlation, in partial, to income were $\mathrm{PB}, \mathrm{PF}, \mathrm{CL}$, and dummy variable (kind of livestock) with significance level of $1 \%$, whereas NBC had significance level of 5\%.

Basically, consumption theory is correlated with demand theory. Demand theory is created using the concept of satisfaction as a reflection of utility measure. Utility itself is an index of satisfaction from goods and services consumed and it can be summed and compared among the consumers (Nicholson, 1996). Total consumption of farm household is much related to the number of family members, price of food and income of beef cattle. Total income of farm household was sourced on beef cattle farming and non-beef cattle in average was IDR $14,737,677.1$ year or IDR $1,228,139.76 /$ month. From this total income, it was allocated to food consumption and non-food consumption and each was calculated IDR $4,912,500 /$ year and IDR 3,642,960/year respectively.

The estimation result of factor variables which influence consumption was in accordance with the economic criteria, where it was, simultaneously, had significant correlation to household consumption with probability of F-test 0.0000 and adjusted $\mathrm{R}^{2}$ of $96 \%$ (Table 4). The expected sign of variables which influenced farm household consumption was appropriate with the theory approach. In partial, variables that correlated to food consumption were NFM, PR, PFish, PM, PO, INBC and lastly the age of husband and wife.

Investment is an allocation of some budget in order to gain profit in the future. Commonly, 
Table 4. Analysis Result of Factors Influencing Beef Cattle Farmer's Household Consumption

\begin{tabular}{|c|c|c|c|}
\hline Variables & Expected sign & Coefficient & Probability \\
\hline Intercept & + & $61.73794 * * *$ & 0.0000 \\
\hline Ln NHM & + & $0.040185 * *$ & 0.0498 \\
\hline Ln PR & - & $-2.556336 * * *$ & 0.0000 \\
\hline Ln PC & - & -0.003049 & 0.9179 \\
\hline Ln PS & + & 0.070743 & 0.3212 \\
\hline Ln PFish & - & $-0.578225 * * *$ & 0.0000 \\
\hline Ln PM & - & $-0.043484^{*}$ & 0.0719 \\
\hline Ln PMilk & - & -0.050267 & 0.2455 \\
\hline Ln PT & - & -0.007221 & 0.2163 \\
\hline Ln PO & - & $-1.810453 * * *$ & 0.0000 \\
\hline Ln AH & - & $-0.056728^{*}$ & 0.0124 \\
\hline Ln AW & + & $0.105381 * * *$ & 0.0000 \\
\hline LnINBC & - & $-0.113579 * * *$ & 0.0000 \\
\hline Probability of F test & & & 0.0000 \\
\hline R-square & & & 0.966664 \\
\hline Adjusted R-square & & & 0.964524 \\
\hline
\end{tabular}

*Significant at $\alpha=10 \%, * *$ Significant at $\alpha=5 \%$ and $* * *$ Significant at $\alpha=1 \%$

Table 5. Analysis Result of Factors Influencing of Beef Cattle Investment

\begin{tabular}{|c|c|c|c|}
\hline Variables & Expected Sign & Coefficient & Probability \\
\hline Intersep & + & $13.63695 * * *$ & 0.0000 \\
\hline Ln NBC & - & $-0.086370 * * *$ & 0.0029 \\
\hline Ln OWT & + & $0.551563 * * *$ & 0.0000 \\
\hline Ln PBC & - & $-0.444818 * * *$ & 0.0000 \\
\hline Ln TC & + & $0.338745 * * *$ & 0.0000 \\
\hline Ln AI & + & 0.171010 & 0.2780 \\
\hline Probability of $\mathrm{F}$ test & & & 0.0000 \\
\hline R-square & & & 0.636538 \\
\hline Adjusted R-square & & & 0.627171 \\
\hline
\end{tabular}

*Significant at $\alpha=10 \%, * *$ Significant at $\alpha=5 \%$ and $* * *$ Significant at $\alpha=1 \%$

investment is divided into financial assets and real assets. Investment into financial assets is taken through currency or capital exchange whereas in the contrary real assets is taken through a productive assets such as make some business (Halim, 2003).

The result of regression analysis was based on statistic criteria from the determination of coefficient value $\left(\mathrm{R}^{2}\right)$ and t-test. Equation of investment had $\mathrm{R}^{2} 63.65 \%$ and adjusted $\mathrm{R}^{2}$ $62.72 \%$ which was greater than 0.5 . It showed that exogenous variable can simultaneously confirm endogenous variable of $62 \%$ with probability of F-test 0.0000 . Regression analysis on factors influencing investment is shown in Table 5. According to the result of partial analysis 
Table 6. The Result of Economic Validation Model of Beef Cattle Farmer's Household

\begin{tabular}{lcc}
\hline \multicolumn{1}{c}{ Endogen Variables } & RMSE & U'Theil \\
\hline Beef cattle production & 0.121610 & 0.004750 \\
Beef cattle farm income & 17.65410 & 0.110775 \\
Consumption of farmer's household & 0.049828 & 0.001621 \\
Beef cattle investment & 0.096787 & 0.003291 \\
\hline
\end{tabular}

Tabel 7. The Change of Price and Technical Aspect Implementation of Beef Cattle to Some Economic Criterias of Beff Cattle Farm Household

\begin{tabular}{lcccc}
\hline \multirow{2}{*}{ Endogen Variables } & \multirow{2}{*}{ Basic value } & Simulation & \multicolumn{2}{c}{ Alteration } \\
\cline { 4 - 5 } & & Value & Unit & $\%$ \\
\hline Beef cattle production & 12.79383 & 12.79383 & No change & - \\
Beef cattle farm income & 58.95968 & 58.95968 & No change & - \\
Consumption of farmer's household & 15.37063 & 15.43901 & 0.06838 & 0.443 \\
Beef cattle investment & 14.70266 & 15.50039 & 0.79773 & 5.146 \\
\hline
\end{tabular}

on variables with correlation to investment of beef cattle farming, it was consisted of NBC, OWT, $\mathrm{PBC}$ and TC.

\section{A Supporting Aid for Beef Cattle Farming}

The research on beef cattle farming is formed on simultaneous analysis, thus correlation between endogenous and exogenous variables is simultaneously correlated. Related to this problem, model validation was performed before the simulation analysis is taken. Model validation was analyzed from normality outcome, Root Mean Square Error (RMSE) value, and coefficient of Theil inequality. The result of validation analysis for simulating input or output price changing is presented in Table 6 . Based on the validation result, it was found that analysis value of Root Mean Square Error (RMSE) was low. According to Pyndick and Rubinfeld (1995) also Greene (2003) RMSE which has minor value is good for prediction. In another hand, model validation using approach of U'Theil criteria resulted value between 1 and 0 , if U'Theil value is closed to 0 (zero) it means that the model had followed the actual data and was a good model. The result of this analysis is suggested in Table 7.

From the simulation towards better improvement both in technical aspect and price changing as a supporting aid for beef catle farming, there were several results:

1. Improving agribusiness implementation and decreasing $15 \%$ of service per conception had made no change towards the production. This was because farmers will attain over-capacity level if there was addition of beef cattle raised, remember that level of agribusiness implementation was still in adequate level and number of family members which was in average only 3.14 people. If there is addition on production, there will be an addition on production cost too.

2. Increasing $15 \%$ of $\mathrm{PB}$ and $\mathrm{NBC}$ had no change towards the income. It could be happen, because increasing of NBC will add $15 \%$ cost production as well. So, cost addition cannot boost the farmer's income.

3. The changing on number of family members and rice price to $15 \%$ caused $0.443 \%$ increase on farm household consumption. This was happened due to the addition of total family members and the raise of rice price which finally yields an addition on allocation for consumption. In the other hand, if only the rice price that change $(10 \%)$ actually it brought no change on farm household 
consumption. Based on this condition, it was concluded that number of family members was the key factor causing the change on farm household consumption.

4. Increasing income of $10 \%$ tend to raise investment of $5.146 \%$. It showed that the income earned by the farmers was not all allocated for farm household consumption but they were also realistic to allocate it for the improvement of beef cattle agribusiness through investment. The result was in line with Albera et al. (2004) finding that simulated profit of the farm is positive gain for farm household.

Based on the result of simulations, it can be concluded that the changes both on input usage and input or output prices were not simultaneously trigger the changes of endogenous variables. This was in accordance with the input factor on the previous discussion that farmer was in rational stage thus improvement of skill or service per conception and price change were not followed by the change of production or income, while the increasing of farmer's income will increase beef cattle investment.

\section{CONCLUSION}

The research can be concluded that beef cattle farm gave profit to farmers and the independent variables simultaneously significant influence to production, income, farm household consumption and beef cattle investment variables. The simulation of changing usage of input factor and price significantly influenced farm household consumption and beef cattle investment.

\section{ACKNOWLEDGMENTS}

The research was supported by "Beasiswa BPPS" scholarship Doctoral Program from Higher Education General Directorate, Ministry of Education, Republic of Indonesia. The authors wish to thank Agriculture Research and Development Board for providing research funding of KKP3T 2010.

\section{REFERENCES}

Albera, L., P. Carnier and A.F. Groen. 2004. Definition of breeding goal for the Piemontese breed: economic and biological value and their sensitivity to production circumstances. Livest. Prod. Sci. 89:67-78

Amir, P. and H.C. Knipscheer. 1989. Conducting On-Farm Research: Procedure and Economic Analysis. Singapore National Printer Ltd. Singapore.

BPS. 2010. Jawa Tengah Dalam Angka 2010. CV Nabawi, Semarang.

Debertin, D.I. 1986. Agricultural Production Economics. Second Edition. Mc Graw-Hill Inc. New Cork.

Ekowati, T., D.H. Darwanto, S. Nurtini and A. Suryantini. 2011. The analysis of beef cattle subsystem agribusiness implementation in Central Java Province. J. of Indonesian Trop. Agric. 36(4):281-289

Falconer, L.L., C.R. Long, and J.M. McGrann. 1996. A decision support aid for beef cattle investment using expert systems. J.Agric and Applied Economics. 28(1):180-192

Greene, W.H. 2003. Econometric Analysis. Fifth Edition. Prentice Hall. Upper Saddle River, New Yersey.

Gujarati, D.N. 2004. Basic Econometric. Fourth Edition. The McGraw-Hill Companies. New York.

Halim, A. 2003. Analisis Investasi. Edisi Pertama. Penerbit Salemba Empat. Jakarta.

Harris, D.L. and S. Newman. 1994. Breeding for profit: synergism between genetic improvement and livestock production. (a reiew). J. Anim. Sci. 72:2178-2200

Herani, G. M., Pervez, M.Wasim, Rajar, A.Wasayo and S.R.A. Indus. 2008. Livestock: A Reliable Source of Income Generation and Rehabilitation of Environment at Tharparkar Institute of Higher education, Karachi University, Sindh University, BIZTEK.

Koutsuyiannis, A. 1985. Theory of Econometric. $2^{\text {nd }}$ Edition. Macmillan. London.

Lestari, C.M.S., R. Adiwinarti, M. Arifin and A. Purnomoadi. 2011. The performance of Java and crossbred bull under intensive feeding management. J. Indonesian Trop. Agric. 36(2):109-113

Nasir, M. 1988. Metode Penelitian. Ghalia Indonesia. Jakarta.

Nicholson, W. 1996. Microeconomic Theory. Basic Principle and Extensions. Seventh Edition. The Dryden Press, Harcourt Brace Collage Publishers, Fort Worth Philadelphia.

Pindyck, R.S. and D.L. Rubenfield. 2005. Microeconomics. Fifth Edition. PrenticeHall, Inc. Upper Saddle River, New Jersey. 
Ponzoni, R.W. and S. Newman. 1989. Developing breeding objectives for Australian beef cattle production. Anim. Prod. 49:35-47

Saragih, B. 2003. Agribisnis. Paradigma Baru Pembangunan Ekonomi Berbasis Pertanian. Edisi Milineum, Terbitan Kedua, Penerbit Yayasan Mulia Persada dan PT Surveyor Indonesia Bekerjasama dengan Pusat Studi
Pembangunan IPB dan Unit for Social and Economic Studies and Evaluation (USESE) Foundation.

Singh, I., L. Square and J. Strauss. 1986. Agricultural Household Models, Extentions, Applications, and Policy. The John Hopkins University Press. London. 